\title{
PREVALENCE AND PROFILE OF SEVERE ANAEMIA IN CHILDREN AGED 1 MONTH TO 14 YEARS ATTENDING TERTIARY CARE HOSPITAL
}

\author{
P. Indira ${ }^{1}$, S. Pratimadevi², J. Rajkumar ${ }^{3}$
}

${ }_{1}^{1}$ Associate Professor, Department of Paediatrics, Andhra Medical College, Visakhapatnam, Andhra Pradesh, India.

${ }^{2}$ Associate Professor, Department of Paediatrics, VIMS, Visakhapatnam, Andhra Pradesh, India.

${ }^{3}$ Postgraduate Student, Department of Paediatrics, Andhra Medical College, Visakhapatnam, Andhra Pradesh, India.

\begin{abstract}
\section{BACKGROUND}

Anaemia is widely prevalent and is a major cause of morbidity. Globally anaemia affects 1.62 billion people which correspond to $24.8 \%$ of the population.(1) The highest prevalence is seen in preschool-age children (47.4\%), and the lowest prevalence is seen in men (12.7\%). Various surveys including the National Family Health Survey (NFHS) have revealed that anaemia is highest in children 6-35 months of age. It is more common in rural areas as compared to urban population.(2) Children, particularly infants living in developing countries are highly vulnerable to infectious diseases. Anaemia is widespread throughout India. Anaemia in young children is a serious concern because it can result in impaired cognitive performance, behavioural and motor development, coordination, language development, and scholastic achievement, as well as increased morbidity from infectious diseases.(3) In addition children may develop lymph node enlargement, petechiae, ecchymosis or bleeding symptoms.(4)
\end{abstract}

\section{MATERIALS AND METHODS}

It is a descriptive study of 200 children aged 1 month to 14 years, attending Department of Paediatrics. KGH, Vizag, with anaemia. Those with severe anaemia were subjected for further evaluation. All lab investigations pertaining to anaemia are done to know the prevalence of anaemia, various aetiological factors, distribution of anaemia by age and sex. Anaemia was diagnosed according to the World Health Organization (WHO) standard for the given age. Data was analysed and interpreted using descriptive and inferential statistics.

\section{RESULTS}

Prevalence of anaemia in males is $53.6 \%$, females is $46.3 \%$, and prevalence of anaemia is more in males than in females in $0-12 \mathrm{yrs}$. age group. Significant history of presenting illness includes fever, pallor, which are the most common, and abdominal mass, history of previous transfusion, jaundice, siblings with similar complaints, facial puffiness, cough, respiratory distress and history suggestive of worm infestation are also seen. Most common positive examination finding in children with anaemia is splenomegaly followed by hepatomegaly. Jaundice, oedema, clubbing, lymphadenopathy, signs of tuberculosis, respiratory distress and signs of renal disease are other most common findings. Aetiological diagnosis in children aged 0-12 yrs. with anaemia are, malaria 31\% thalassemia $18 \%$, sickle cell anaemia $11 \%$, iron deficiency anaemia $11 \%$, anaemia of chronic disease $7 \%$, sickle thalassemia $3 \%$, malignancies $3 \%$, sepsis $3 \%$, dengue $2 \%$, nephrotic syndrome $2 \%$, dimorphic anaemia $2 \%$, aplastic anaemia $2 \%$, thalassemia intermedia $2 \%$ and others $4 \%$. 9. Prevalence of history of requirement of transfusion in the present study is $50.7 \%$ and children who need more than one transfusion or those requiring regular transfusions is $32 \%$.

\section{CONCLUSION}

- Anaemia is the most common co-morbid condition in children, with malaria, haemoglobinopathies and iron deficiency anaemia as the most common causes.

- $\quad$ Prevalence of anaemia and severe anaemia is more common after 6 years and is more common in girls.

\section{KEY WORDS}

Anaemia, Male, Female, Severity, Clinical Features, Blood Transfusions.

HOW TO CITE THIS ARTICLE: Indira P, Pratimadevi S, Rajkumar J. Prevalence and profile of severe anaemia in children aged 1 month to 14 years attending tertiary care hospital. J. Evolution Med. Dent. Sci. 2019;8(06):385-388, DOI: $10.14260 /$ jemds/2019/85

\section{BACKGROUND}

Anaemia, reduction in haemoglobin in the peripheral blood which is below normal for age and sex, is the cause for morbidity and in some cases mortality in children.(5) Anaemia in most cases is preventable and treatable.

'Financial or Other Competing Interest': None.

Submission 13-12-2018, Peer Review 25-01-2019,

Acceptance 01-02-2019, Published 11-02-2019.

Corresponding Author:

Dr. P. Indira,

Plot No. 26, Palace Compound,

Pedawaltair, Visakhapatnam-17,

Andhra Pradesh, India.

E-mail:indiraguda07@gmail.com

DOI: $10.14260 /$ jemds $/ 2019 / 85$

(c) (i) $९$
Anaemia, in addition to morbidity from infectious diseases, impairs cognitive, behavioural, motor, coordination, language development and scholastic performance ${ }^{(6)}$ and is treatable in most cases. Anaemia is widespread in India and more in rural areas. In Andhra Pradesh, prevalence of anaemia in children is $70.8 \%$ (mild), $43.5 \%$ (moderate), and $3.6 \%$ (severe). (NFHS-3) Anaemia is an indicator of nutritional status \& it usually results from deficiency of iron and vitamin B12 \& others.(7) May contribute to excess cardiovascular or respiratory work.

\section{Aims \& Objectives}

- To determine the prevalence of severe anaemia.

- Various etiological factors.

- Distribution of anaemia among male and female sex.

- Distribution of anaemia in various age groups. 
Total No. of Cases Studied 200.

\section{Duration of Study \\ 1 Year.}

\section{MATERIALS AND METHODS}

The descriptive study of Children from 1 month to 14 years attending the Department of Paediatrics. KGH, Vizag with anaemia were taken into study. Those with severe anaemia were subjected for further evaluation. All lab investigations pertaining to anaemia are done.

\section{Few of them were-}

- $\quad \mathrm{CBC}-\mathrm{Hb} \%$

- TC.

- DC.

- ESR.

- Platelet count.

- Peripheral smear.

- Reticulocyte count.

- $\quad$ MCV and other RBC Indices.

- Iron studies.

- Haemoglobin electrophoresis.

- Bone marrow aspiration and Biopsy.

- S. Creatinine.

- $\quad$ Thyroid \& Liver Function tests.

- G6PD Screen.

- Osmotic fragility test.

- Smear for M. P.

- $\quad$ QBC for M. P.

\section{RESULTS}

\begin{tabular}{|c|c|c|}
\hline Age in Years & No. of Patients & Percentage \\
\hline 1 Month-1 Year & 41 & $20.50 \%$ \\
\hline 1 Year -5 Years & 77 & $38.50 \%$ \\
\hline 5 Years -14 Years & 82 & $41 \%$ \\
\hline Total & 200 & $100 \%$ \\
\hline Table 1. Prevalence of Severe Anaemia in Different Age \\
Groups in Children \\
\hline
\end{tabular}

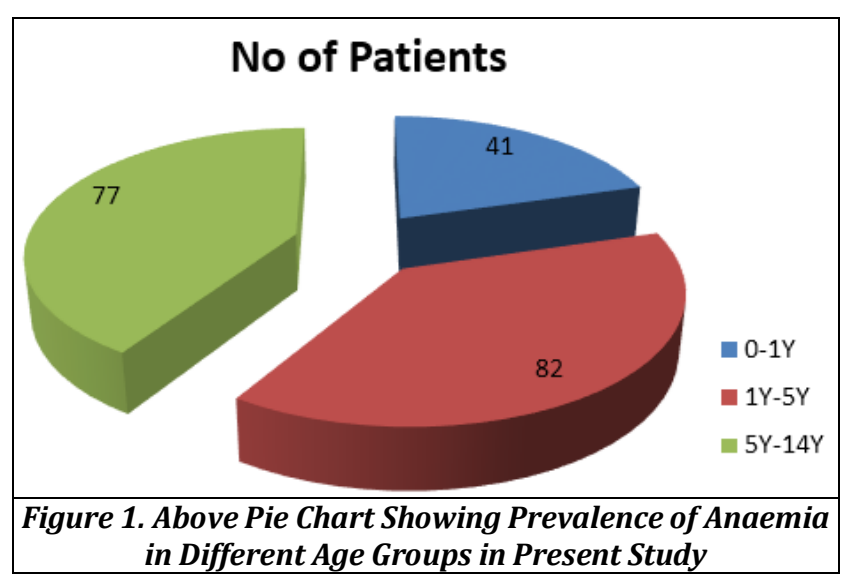

Prevalence of anaemia in children aged 1 month to 1 year is $20.5 \%, 1-5$-year age group is $38.5 \%$ and in $5-14$ year age group is $41 \%$. In this study Prevalence of anaemia is more in children aged 5-14 years, followed by 1-5 year age group and 1 month - 1 year age group.

\begin{tabular}{|c|c|c|c|}
\hline & Male & Female & Total \\
\hline I Month-1 Year & 23 & 18 & 41 \\
\hline 1 Year- 5 Years & 43 & 34 & 77 \\
\hline 5 Years -14 Years & 48 & 34 & 82 \\
\hline \multicolumn{2}{|c|}{ Table 2. Prevalence of Anaemia by Age and Sex } \\
\hline
\end{tabular}

1Month-1Year $\square$ 1Year-5Years $\square$ 5Years-14Years

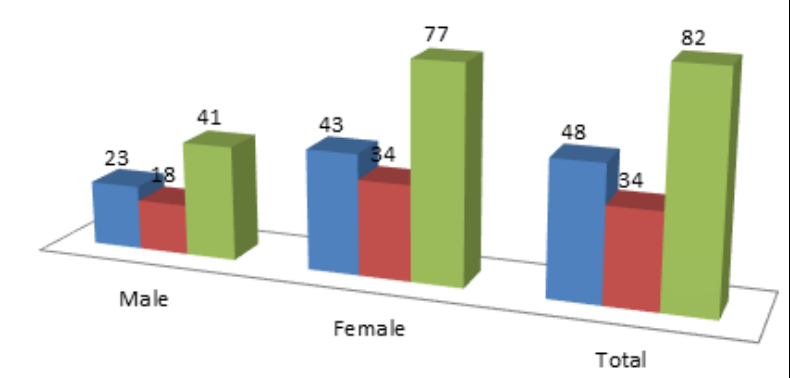

Figure 2. Prevalence of Anaemia by Age and Sex

Prevalence of severe anaemia in male children in the age group of 1 month to 1 year is $11.5 \%$ and in female children of $9 \%$. In children in the age in the age group of 1 year to 5 years Prevalence of severe anaemia in males is $21.5 \%$ and in female children is $17 \%$. And Prevalence of severe anaemia in the age group of 6 to 14 years is $24 \%$ and in females is $17 \%$.

\begin{tabular}{|c|c|c|c|c|}
\hline & Mild & Moderate & Severe & Total \\
\hline Male & $16(57.1 \%)$ & $47(52.2 \%)$ & $44(53.6 \%)$ & 107 \\
\hline Female & $12(42.8 \%)$ & $43(47.7 \%)$ & $38(46.3 \%)$ & 93 \\
\hline Total & $\mathbf{2 8}$ & $\mathbf{9 0}$ & $\mathbf{8 2}$ & $\mathbf{2 0 0}$ \\
\hline \multicolumn{6}{|c}{ Table 3. Prevalence of Severity of Anaemia by Sex } \\
\hline
\end{tabular}

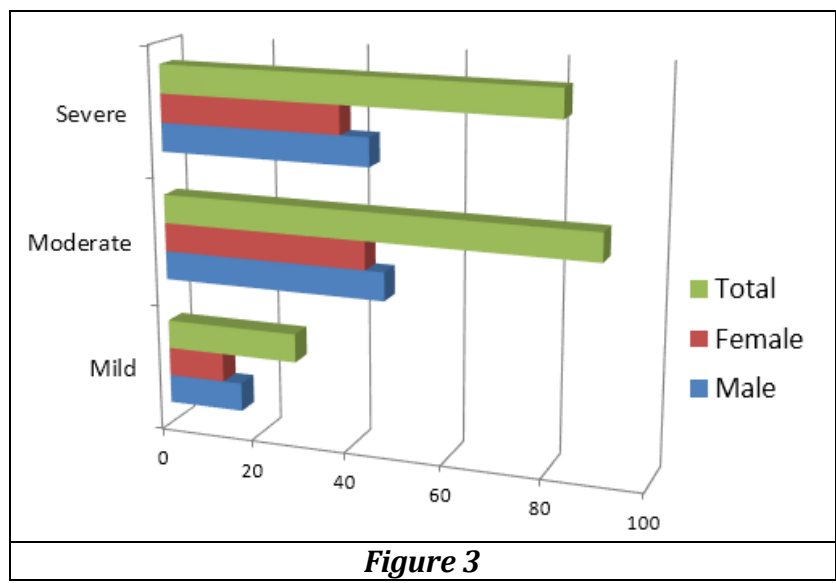

In children, male children are more commonly found to be with all degrees of mild, moderate and severe anaemia when compared to female children.

\begin{tabular}{|c|c|}
\hline Splenomegaly & $\mathbf{1 0 4}$ \\
\hline Hepatomegaly & 75 \\
\hline Jaundice & 8 \\
\hline Oedema & 9 \\
\hline Clubbing & 7 \\
\hline Lymphadenopathy & 3 \\
\hline Signs of tuberculosis & 11 \\
\hline Signs of renal disease & 2 \\
\hline Respiratory distress & 23 \\
\hline
\end{tabular}

Table 4. Positive Examination Findings in Children with Anaemia 


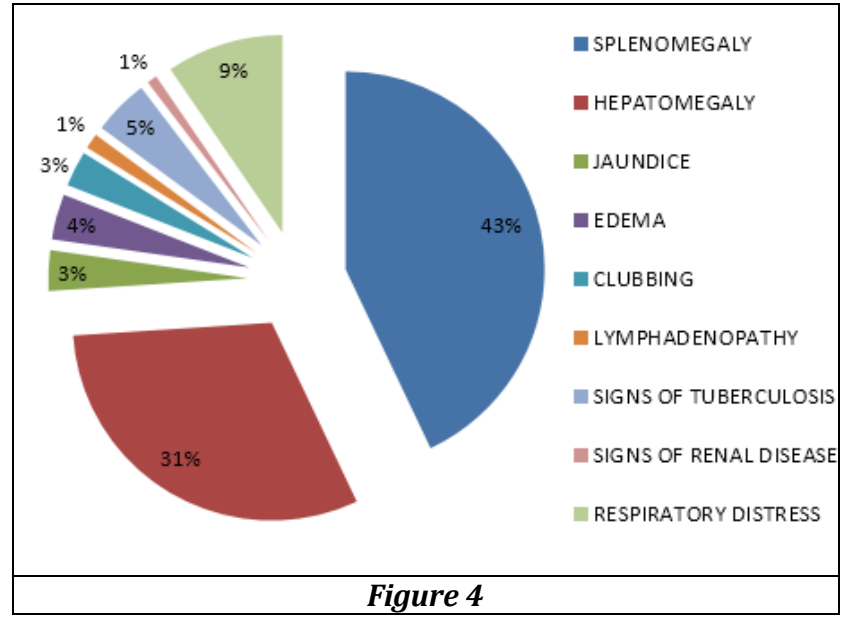

The most common positive examination finding in children with severe anaemia is splenomegaly followed by hepatomegaly. Both hepatomegaly and splenomegaly is also there in a significant number of cases and in some jaundice is also found in association.

\begin{tabular}{|c|c|}
\hline Malaria & $\mathbf{3 1 \%}$ \\
\hline Thalassemia & $18 \%$ \\
\hline Iron Deficiency Anaemia & $11.00 \%$ \\
\hline Sickle Cell Anaemia & $11 \%$ \\
\hline Anaemia of Chronic Disease & $7 \%$ \\
\hline Sickle Beta Thalassemia & $3 \%$ \\
\hline Others & $4.00 \%$ \\
\hline Malignancies & $3 \%$ \\
\hline Septicaemia & $3 \%$ \\
\hline Dengue & $2 \%$ \\
\hline Nephrotic Syndrome & $2 \%$ \\
\hline Dimorphic Anaemia & $2 \%$ \\
\hline Thalassemia Intermedia & $2 \%$ \\
\hline Aplastic Anaemia & $2 \%$ \\
\hline HDN & $1.00 \%$ \\
\hline Table 5. Aetiological Diagnosis In Children With Severe \\
Anaemia & \\
\hline
\end{tabular}

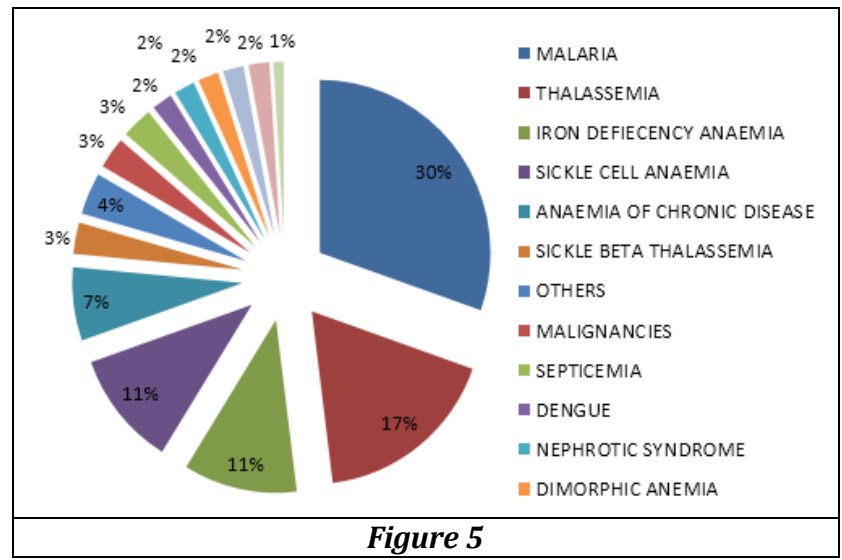

In this study, Malaria is the most common etiological factor in $31 \%$ of children, Thalassemia in $18 \%$, Iron Deficiency Anaemia in 11\%, Sickle Cell Anaemia in 11\%, Anaemia of Chronic Disease in 7\%, Sickle Beta Thalassemia in $3 \%$, Malignancy in $3 \%$, Septicaemia in $3 \%$, Dengue in $2 \%$, Nephrotic Syndrome in 2\%, dimorphic anaemia(8) in $2 \%$, Aplastic Anaemia in 2\%, HDN $1 \%$ and others 4\%. Others include Failure to Thrive, Aspiration Pneumonia,
Bronchiolitis, Pneumonia, Empyema, Chronic Lung Disease, Clotting Disorders, Hydrocephalus, Viral Hepatitis, HIV infection. These might not be the definitive aetiology of severe anaemia rather the morbidity that contributed to the pathology severe anaemia is found in association with these diseases in some cases.

\begin{tabular}{|c|c|}
\hline Gender & Receiving Blood Transfusions \\
\hline Male & 37 \\
\hline Female & 28 \\
\hline Total & $\mathbf{6 4}$ \\
\hline
\end{tabular}

Table 6. Children with Severe Anaemia Who Are in Need of Multiple Blood Transfusions

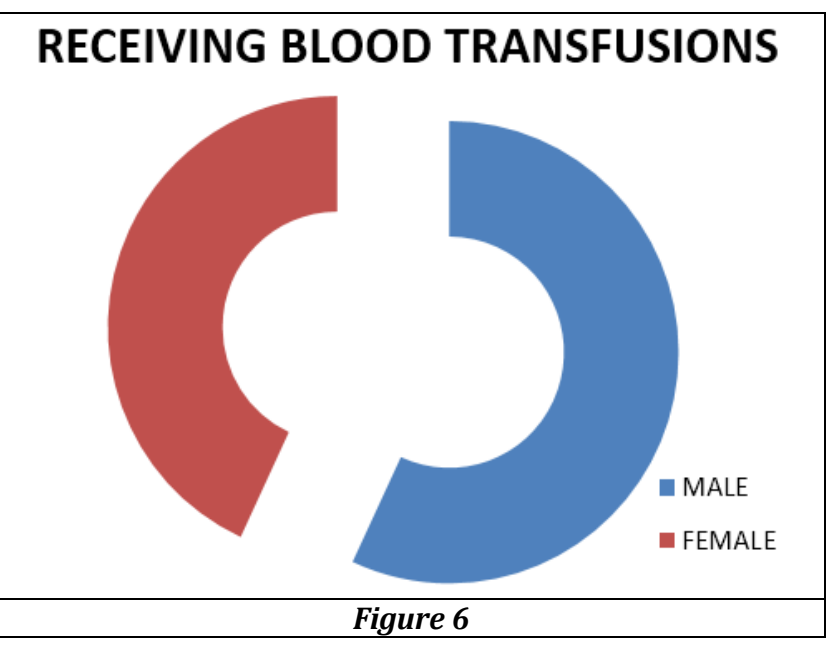

Out of 200 children in the study group, children with hemoglobinopathies who are in need of multiple blood transfusions in males is $18.5 \%$ in the study group. Female children are $14 \%$. Thalassemia is the most common etiological factor.

\section{DISCUSSION}

Anaemia is an important nutritional problem encountered in children. The present study was undertaken in 250 school children in the age group of 8 to 14 years to study the prevalence of anaemia and to study the association of certain risk factors with the prevalence of Anaemia.

\section{CONCLUSION}

- Anaemia is the most common co-morbid condition in children, with malaria, hemoglobinopathies, and iron deficiency anaemia is the most common cause.

- Prevalence of anaemia and severe anaemia is more common after 6 years and is more common in girls.

- Malaria and haemoglobinopathies are the most common causes in any age group.

- Most common presenting complaint is fever followed by pallor.

- Most common finding on examination is hepatosplenomegaly.

- Most of the causes of severe anaemia are preventable and readily treatable ${ }^{(9)}$ in most cases and IFA prophylaxis and early treatment of infectious diseases play a major role in the current scenario. 
Preventive measures to decrease the severity of illness(10)

- $\quad$ Strengthening of primary health care in early screening of anaemia.

- $\quad$ Screening for sickling in secondary health care facilities.

- High index of suspicion and primary investigation for haemoglobinopathies in children with anaemia.

- Prevention of vector borne disease predisposing to anaemia.

- Effective treatment of malaria with radical therapy in indicated cases.

- Iron supplementation for children with IDA and antihelminthic measures for hook worm infestation.

- Education of parents regarding nutrition.

\section{REFERENCES}

[1] Vinaykumar, Abbas A, Fausto N, et al. Robbins and Cotran Pathologic basis of disease. $8^{\text {th }}$ edn. Elsevier Saunders 2009.

[2] Koch WC. Parvovirus B19. In: Behrman RE, Kliegman RM, Jenson HB, eds. Nelson Textbook of Pediatrics. 16th edn. Philadelphia: Saunders 2000: p. 964-6.

[3] Schwartz E. Anaemias of inadequate production. In: Behrman RE, Kliegman RM, Jenson HB, eds. Nelson Textbook of Pediatrics. $16^{\text {th }}$ edn. Philadelphia: Saunders 2000: p. 1463-72.
[4] Nelson WE, Behrman RE, Kliegman R, Nelson Textbook of pediatrics. $15^{\text {th }}$ edn. Philadelphia: W.B Saunders 1996: p. 1399.

[5] Segel GB. Enzymatic defects. In: Behrman RE, Kliegman RM, Jenson HB, eds. Nelson Textbook of Pediatrics. 16 th edn. Philadelphia: Saunders 2000: p. 1488-91.

[6] Irwin JJ, Kirchner JT. Anaemia in children. Am Fam Physician 2001;64(8):1379-87.

[7] Subrahmanyam S, Aparna. "Development of Agriculture in Andhra Pradesh", Background paper. Andhra Pradesh Human Development Report, CESS, Hyderabad. 2007.

[8] Nathan DG, Orkin SH, Oski FA, et al. Nathan and Oski's Hematology of infancy and childhood. $5^{\text {th }}$ edn. Philadelphia: Saunders 1998: p. 382.

[9] Agarwal B, Pedicon B. Etiologic classification and major diagnostic features of anaemia in children. 2005.

[10] Ritu S, Ashok D, Vithal TP, et al. A hospital based study on anaemia prevalence in children of an Indian Island. Int J Paediatrics 2017;5(12):6245-52. 